minali in medio umbonata; areis centralibus longitudinaliter valde liratis, umbonibus lavibus, elevatis, subproductis; ligamento squammulato; squammulis mucronatis, imbr icatis, apicibus suberectis.

Hab. Sydney, under stones, low water (Mr. Strange).

This species is remarkable for the somewhat triangular imbricate scales of the ligament ending in sharp pointed mucrones; the ligament is tesselated with pale fuscous and dark brown; the ribs on the lateral areas are four, muricated with sharp granules.

9. Chiton versicolor, A. Adams (Pl. XVI. fig. 5). C.testa oblongo-ovali, elevatiuscula, rufo, albo, fuscoque varie picta; valvis obtusis, in medio longitudinaliter sulcosis, umbonibus acutis subrostratis, apicibus deflexis ; valva terminali in medio umbonata; ligamento tenuiter granoso-coriaceo rufo-fusco, maculis albis quinque ornato.

$H a b$. Sydney, under stones, low water (Mr. Strange).

A prettily variegated species, with the scales on the ligament minute, imbedded and not imbricate, and the entire upper surface of the valves delicately shagreened.

November 9, 1852.

J. S. Bowerbank, Esq., F.R.S., in the Chair.

The following papers were read :-

1. Descriptions of a NeW GeNus, AND OF SEVERal NeW SPEcies, of Mollusca, from the Cumingian Collection. By drthur Anams, F.L.S. etc.

\title{
Family Solenellide.
}

Animal oblong. Mantle open in the entire length; margin double, outer edge fimbriated; hind outer edge ending in two callous conical processes immediately below the respiratory orifice. Respiratory orifice continuous with the opening of the mantle, the margin fringed; anal siphon simple-edged, tubular, elongate, muscular, produced beyond the fringed mantle-margin which surrounds its base. Gill single on each side, attached the whole length. Labial palps elongate, fringed at their margins, and surrounded at their base by a thin dilated membrane. Foot large, compressed, geniculate, ending anteriorly in a folded ovate disc with crenate margins.

Shell thin, not pearly within. Hinge-margin with comb-like teeth. Ligament external. 


\section{Genus Neilo, A. Adams.}

Testa transversa aquivalvis, inaquilateralis, epidermide fusco tenui induta, latere postico hians. Dentibus cardinalibus, nullis, lateribus anticis et posticis plurimis in serie rectiuscula dispositis; dentilus parvis acutis; impressionibus muscularibus subdistantibus, impressione pallii sinu magno; ligamento externo elongato.

This genus differs from Solenella, not only in its Leda-like form, but in the hinge-margin having as many teeth anteriorly as posteriorly. In Solenella the series of teeth is confined to the fulcrum to which the external ligament is attached;-in this genus the teeth extend along the entire hinge-margin.

Neilo Cumingir, A. Adams. N. testa transversa, aquivalvi incequilaterali, epidermide tenui viridi-fusco obtecta, transverse concentrice sulcata; latere antica clauso, rotundato, postico, longiore, subangulato, hiante, margine truncato flexuoso, superne auriculato.

From the circumstance of the hind margin gaping considerably and being divided as if for two siphons, the anal and branchial tubes in this animal are probably distinct and elongated, as in Leda. The genus Neilo, in fact, will represent Leda, of the family Nuculida, in a distinet family, Solenellida, characterized by the external ligament of the hinge. It is from the shores of New Zealand.

Concholepas (Coralliobia) fimbriata, A. Adams. C. testa ovata alba, longitudinaliter radiatim costata, transverse lamellosa, lamellis pulcherrime fimbriatis; spira minuta, anfractu ultimo amplo; apertura ovali antice attenuata, subcanaliculata; labio excavato incurvato, margine externo dilatato et valde reflexo; labro acuto, margine late dilatato et eleganter fimbriato.

$H a b$. Cagayan, province of Misamis, island of Mindanao, Philippines. On the coral reefs at low water $(\boldsymbol{H}$. C. $)$. Mus. Cuming.

Externally this curious shell resembles Concholepas, but the absence of the two teeth on the fore part of the outer lip prevents it being strictly referred to that genus. In the character of the inner lip, and in its place of habitation on coral reefs, it approaches Leptoconchus, and perhaps it has affinities also with Pedicularia. I have thought it best, until the animal is known, to regard it as a subgenus of Concholepas, under the name of Coralliobia.

Paxiluus minor, A. Adams. P. testa dextrorsa, ovali, tenui, epidermide fusca obtecta; anfractibus septem convexis, longitudinaliter confertim costellatis vel valde striatis; apertura suborbiculari, ascendente, antice subproducta; peristomate duplici, externo reflexo, dilatato; labio plica dentiformi valida instructo.

Hab. - ?

I believe the little shell described above to be a dextral species of 
the genus Paxillus, described by my brother and myself in the 'Annals' a few months ago. We there considered the genus to belong, possibly to Auriculida; but an examination of this species, and a better knowledge of the locality where the shells have been found, lead us to place them amongst the Helicida.

Diprommatina Bensoni, A. Adams. D. testa minima vix rimata sinistrorsa, cylindrico-ovata, costellata, costulis distantibus obliquis regularibus; anfractibus sex, convexis, apice subobtuso; apertura rotundata; peristomate duplicato, externo expanso reflexo, interno recto, margine flexuoso.

$H a b$. On the banks of a river, Moreton Bay, E. Australia (Mr. Strange).

This very pretty little shell agrees in all its characters with the genus Diplommatina of Mr. Benson, after whom I have named it. There is some difficulty in the location of this genus. Mr. Benson says distinctly that the eyes are "on the posterior part of the tentacula, at their base," but he says there is no operculum. Mr. Gray, on the other hand, has described the operculum. The true position is probably in Truncatellida.

Crassatella speciosa, A. Adams. C. testa transverse ovata suboquilaterali, pallida, epidermide tenui fusca induta, concentrice plicata; plicis confertis regularibus; latere postico rotundato, antico acuminato subrostrato, angulato, margine ventrali convexo, antice sinuato.

Hab. Bay of Campeachy. Mus. Cuming.

The beaks in this species are acute and close together, and rather more deeply plicate than the rest of the surface of the valves; there is an obtuse oblique and angular ridge extending from the umbones to the ventral margin.

Crassatecha lavis, A. Adams. C. testa ovato-transversa crassa, tumida, subaquilaterali, castanea, lavigata, concentrice striata, natibus subsulcatis; latere postico rotundato, antico producto subrostrato, maryine oblique truncato, carina obtusa a natibus ad basin decurrente instructo, posteriori sulcato, margine ventrali convexo antice sinuato.

Hab. La Guayra (M. Le Marie, French Navy). Mus. Cuming.

A large smooth pale chestnut shell beaked anteriorly and with a prominent obtuse keel extending from the beaks to the fore part of the ventral margin, and a broad shallow groove behind it ; the lunule is ovate lanceolate, and the beaks are transversely sulcate.

Crassatella obscura, A. Adams. C. testa ovato-trigonali, transversa, subcequilaterali, compressa, nigro-fusca, apicibus transverse corrugata, ad umbonem plicata; latere antico rotundato, postico subtruncato; margine valvarum intus crenulato.

Hab. China Seas, deep water. Mus. Cuming.

A small brown-black species, with the valves only plicate near the beaks and their inner margins finely crenulated. 
Crassatella bellula, A. Adams. C. testa ovato-trigonali, subaquilaterali, carneo-fulva, immaculata, transverse concentrice plicata; plicis obtusis subconfertis regularibus, antice undulatis, subevanidis (sub lente rugulosis); latere postico rotundato, antico vix truncato; umbonibus acutis parvis approximatis.

Hab. New Zealand (Mr. Hart). Mus. Cuming.

A beautiful pinkish yellow species, without any spots or markings, with the plice on the fore part undulated and rugulose under the lens.

Crassatella truncata, A. Adams. C. testa ovata, compressa, carnea, pallidiori ad partem anticam, radiis angustis inconspicuis ornata, incequilaterali, latere antico breviori et rotundato, postico dilatato et truncato, linea elevata e umbonibus ad marginem ventralem; transversim valde costata, costis acutis subimbricatis.

Hab. China Sea, deep water (A.Adams).

This is a small pale pink or flesh-coloured species, strongly ribbed, the ribs being sharp, prominent and imbricated; the posterior side is dilated and truncate, and the surface of the valves is marked w th faint linear radiating lines.

Crassatella compta, A. Adams. C. testa ovato-trigonali, subaquilaterali, apicibus antrorsum curvatis, rufescenti, transverse concentrice plicata; plicis validis, regularibus subdistantibus; latere antico angustiori, postico latiori rotundato, interne purpurascente.

$H a b$. China Sea, deep water (A. Adams).

This is a small red species, with prominent curved beaks, strongly plicate transversely, and of a purplish pink colour in the interior of the valves.

Crassatella concinna, A. Adams. C. testa ovato-transversa subrequilaterali, epidermide tenui fisca obtecta, utrinque rotundata, concentrice plicata, plicis validis regularibus rufofusco articulatis; interstitiis creberrime longitudinaliter striatis; umbonibus acutis confertis.

$H a b$. China Sea, deep water ( $A$. Adams).

A small fuscous species, of an ovate form, rounded at both ends, with the transverse plicæ strongly produced and prettily articulated with brownish red. 